\title{
PEMBELAJARAN KOOPERATIF TIPE TEAM ASSISTED INDIVIDUALIZATION (TAI): DAMPAK TERHADAP HASIL BELAJAR FISIKA SISWA
}

\author{
Tri Ariani \\ STKIP PGRI Lubuklinggau, Indonesia \\ e-mail: triariani.ta@gmail.com
}

Diterima: 17 Juli 2017. Disetujui: 5 Oktober 2017. Dipublikasikan: 28 Oktober 2017

\begin{abstract}
Abstrak: Penelitian ini bertujuan untuk mengetahui pengaruh hasil belajar fisika siswa pada ranah kognitif dengan menggunakan model pembelajaran kooperatif tipe Team Assisted Individualization (TAI) siswa kelas X SMA Negeri 8 Lubuklinggau Tahun Pelajaran 2016/2017. Jenis penelitian ini adalah penelitian eksperimen, dengan desain penelitian berbentuk pre-test dan post-test kontrol group design. Teknik pengumpulan data dalam penelitian ini adalah tes berbentuk soal essay sebanyak 7 butir soal. Kelas sampel diambil kelas X.1 dan kelas X.2. Nilai rata-rata kelas eksperimen pada tes awal sebesar 40,64 dan tes akhir sebesar 83,41. Sedangkan nilai rata-rata kelas kontrol pada tes awal sebesar 32,16 dan pada tes akhir sebesar 75,73. Dengan $t_{\text {hitung }}=2,604 \mathrm{dk}=48 \mathrm{dan} \alpha=0,05$, maka nilai $t_{\text {tabel }}$ adalah 1,684. Jadi $t_{\text {hitung }}>t_{\text {tabel }}$, maka terima $\mathrm{H}_{a}$ dan tolak $\mathrm{H}_{0}$. Berdasarkan analisis tersebut dapat disimpulkan ada pengaruh model pembelajaran kooperatif tipe Team Asissted Individualization (TAI) terhadap hasil belajar fisika siswa.
\end{abstract}

Kata Kunci: fisika, hasil belajar, kognitif, kooperatif tipe time assisted individualization.

\section{TEAM ASSISTED INDIVIDUALIZATION (TAI) COOPERATIVE LEARNING: THE IMPACT ON STUDENTS' PHYSICS LEARNING OUTCOMES}

\begin{abstract}
The research aims to know the influence of students studying physics by using cooperative learning model Team Assisted Individualization (TAI) type in learning physics on class X SMAN 8 Lubuklinggau the Academic Year 2016/2017. This type of research is experimental research, the research design used in the form of pre-test and post-test control group design. Data collection techniques in this research are essay test in the form of as much as seven items. The essay is to determine students' learning outcomes in the cognitive domain. The samples were taken from class X.1 and class X.2. The average value of the experimental class in initial tests was at 40.64 and 83.41 for the final test. While the average value of the initial test in control class was at 32.16 and for the final test at 75.73. With $t=2.604 d f=48$ and $\alpha=0.05$, $t_{\text {table }}$ value is 1.684 . So $t_{\text {count }}>t_{\text {table, }}$, then accept and reject HO Ha. Based on this analysis we can conclude the results of the experimental class which is learning using cooperative learning model Assisted Individualization Team (TAI) type is higher than the average value of the control class that using conventional cooperative learning.
\end{abstract}

(C) 2017 Pendidikan Fisika, FTK UIN Raden Intan Lampung

Keywords: physics, learning outcome, cognitive, cooperative time assisted individualization type.

\section{PENDAHULUAN}

Pendidikan memegang peranan penting untuk menjamin kelangsungan hidup suatu negara dan bangsa (Herlanti, Rustaman, Rohman, \& Fitriani, 2012). Pendidikan menuntut guru untuk mengembangkan potensi siswa berdasarkan standar kompetensi yang ada. (Yulianti \& Putra, 2012). Pendidikan yang bermutu, akan menghasilkan sumber daya manusia yang berkualitas dan berdaya saing tinggi. (Gumrowi, 2016).

Fisika merupakan hasil kegiatan manusia berupa pengetahuan, gagasan 
dan konsep yang terorganisasi tentang alam sekitar yang diperoleh dari serangkaian pengalaman melalui proses ilmiah (Perdana, 2017). Fisika diperlukan dalam kehidupan sehari-hari, namun tidak sedikit orang yang menganggap fisika sebagai ilmu yang kurang menarik. Hal ini disebabkan fisika erat hubungannya dengan ide-ide atau konsep-konsep abstrak yang membutuhkan penalaran ilmiah. Kesulitan untuk memahami konsep-konsep fisika yang dialami oleh siswa bukan hanya karena faktor materi yang disampaikan, tapi siswa kurang dilibatkan dalam proses belajar mengajar. (Komikesari, 2016)

Berdasarkan hasil pra penelitian beberapa penyebab rendahnya hasil belajar yaitu pemilihan metode dan media pembelajaran yang digunakan oleh guru pada proses pembelajaran sangat kurang tepat dan pengelolaan kegiatan pembelajaran yang masih belum dapat membangkitkan motivasi belajar siswa secara optimal (Gumrowi, 2016a). Strategi pembelajaran yang digunakan di sekolah akan berhubungan langsung dengan keberhasilan proses pembelajaran siswa (Erlinda, 2017).

Terdapat beberapa permasalahan yaitu pembelajaran yang digunakan masih menggunakan metode tanya jawab dan ceramah, sehingga pembelajaran berpusat pada guru. Selain itu hasil belajar siswa pada mata pelajaran fisika belum sesuai dengan yang diharapkan. Hal ini terlihat dari nilai ulangan harian pada siswa tahun pelajaran 2015/2016 dari 123 siswa. Hanya 52 siswa (39\%) yang sudah mencapai Kriteria Ketuntasan Minimal (KKM) sedangkan 71 siswa $(61 \%)$ belum mencapai KKM yang ditetapkan oleh sekolah yaitu 75. Pada dasarnya, guru fisika di SMA Negeri 8 Lubuklinggau sudah mengupayakan perbaikan dalam proses pembelajaran akan tetapi hasil yang diperoleh belum optimal.

Proses pembelajaran itu sendiri berupa hubungan interaksi antara siswa, guru, perlengkapan dan kurikulum. Suatu kegiatan pembelajaran dapat dikatakan berjalan dengan baik dan efektif apabila hubungan interaksi tersebut dapat saling mendukung. Guru sebagai salah satu komponen hubungan interaksi pada proses pembelajaran, bertugas membimbing dan mengarahkan siswa belajar dan bagaimana supaya mendapatkan hasil belajar yang maksimal. Besar kecilnya peranan guru dalam proses pembelajaran untuk mencapai hasil belajar yang baik sangat tergantung pada tingkat penguasaan materi, pemilihan pendekatan, metode yang digunakan dan model pembelajaran yang akan dipakai. (Khusaini, 2017). Sains tidak hanya menyampaikan apa yang kita ketahui, tetapi lebih jauh lagi bagaimana kita menjadi tahu dan mengapa kita mempercayainya. (Herlanti et al., 2012). Proses mengingat kembali tentang apa yang telah terlupa dan mengingat untuk memahami ilmu pengetahuan baru dalam proses berpikir seseorang (Saregar, Latifah, \& Sari, 2016)

Proses pembelajaran yang baik seharusnya banyak melibatkan siswa, sehingga siswa mempunyai peran penting dalam kegiatan belajar mengajar. Tetapi, dilihat dari kondisi siswa saat proses pembelajaran sering ditemukan hampir keseluruhan siswa banyak terdiam diri dan kurang percaya diri dalam mengeluarkan pendapatnya. Apabila guru memberikan pertanyaan dijawab serentak, hal ini membuktikan bahwa siswa kurang percaya diri dalam menjawab pertanyaan secara individu. Siswa juga tidak berani bertanya kepada guru jika tidak mengerti padahal guru telah memberikan kesempatan dan mereka lebih berani bertanya kapada sesama temannya. Kemudian saat guru bertanya hanya siswa-siswa tertentu yang merespon yang lainnya berdiam diri dan mengerjakan kegiatan lainya yang tidak berhubungan dengan pembelajaran yang berlangsung. (Wardani, Suwatra, \& Wirya, 2015) 
Pembelajaran kooperatif tipe TAI ini merupakan suatu model pembelajaran yang mengkombinasikan pembelajaran kooperatif dengan pembelajaran individual (Hermawan \& Paloloang, 2014; Saregar, Diani, \& Kholid, 2017). Model pembelajaran kooperatif dapat melibatkan siswa secara aktif diantaranya adalah Team Assisted Individualization. Dalam model pembelajaran Team Assisted Individualization (TAI) adalah siswa dituntuk aktif dalam kelompoknya. (Abidin, 2013) menyebutkan beberapa kelebihan dan kelemahan model pembelajaran kooperatif tipe Team Assisted Individualization (TAI), kelebihannya diantaranya : 1)Siswa akan termotivasi belajar karena hasil belajar dinilai secara teliti dan cepat, 2)para siswa terbina kemampuan komunikasinya, 3)perilaku yang mengganggu dan konflik antar pribadi akan terkurangi melalui penanaman prinsip kerja kooperatif, 4) program ini sangat membantu siswa yang lemah dan sekaligus meningkatkan prestasi belajar siswa secara keseluruhan. Sedangkan kelemahan Model Pembelajaran Kooperatif Tipe Team Assisted Individualization (TAI) diantaranya: 1) diperlukan media pembelajaran yang lengkap dan memadai, 2) waktu yang lama untuk pembuatan perangkat pembelajaran, 3) diperlukan kinerja kritis evaluatif dari guru selama siswa bekerja dalam kelompok. Berdasarkan latar belakang yang telah dikemukakan di atas maka tujuan penelitian ini adalah untuk mengetahui pengaruh hasil belajar fisika siswa yang diajarkan dengan menggunakan model pembelajaran kooperatif tipe Team Assisted Individualization (TAI) pada siswa kelas $\mathrm{X}$ SMA Negeri 8 Lubuklinggau.

\section{LANDASAN TEORI}

\section{Model Pembelajaran Kooperatif}

Fathurrahman menjabarkan model pembelajaran kooperatif adalah bentuk pembelajaran yang menggunakan pendekatan melalui kelompok kecil siswa untuk bekerja sama dan memaksimalkan kondisi belajar dalam mencapai tujuan belajar (Fathurrohman, 2015). Model pembelajaran kooperatif merupakan model pembelajaran berorientasi pada tiap individu menyambung pencapaian tujuan individu mencapai tujuan bersama. Eggen and Kauchak dalam (Trianto, 2013) menjabarkan bahwa model pembelajaran kooperatif merupakan sebuah kelompok strategi pengajaran yang melibatkan siswa bekerja secara berkolaborasi untukmencapai tujuan bersama.

Rusman menyatakan bahwa pembelajaran kooperatif (cooperative learning) merupakan bentuk pembelajaran dengan cara siswa belajar dan bekerja dalam kelompok-kelompok kecil secara kolaboratif yang anggotanya terdiri dari empat sampai enam orang dengan struktur kelompok yang bersifat heterogen. Pada hakikatnya cooperavite learning sama dengan kerja kelompok, oleh karena itu, banyak guru yang mengatakan tidak ada sesuatu yang aneh dalam pembelajaran kooperatif karena mereka beranggapan telah biasa melakukan pembelajran cooperative learning dalam bentuk belajar kelompok. (Rusman, 2013)

\section{Model Pembelajaran Kooperatif Tipe Team Assisted Individualization (TAI)}

Model pembelajaran kooperatif tipe Team Assisted Individualization (TAI) yang dikembangkan oleh Slavin (1995) merupakan salah satu model pembelajaran yang menggunakan kelompok yang heterogen yang terdiri dari 4-5 orang yang saling bekerja sama dalam kelompokkelompok meraka untuk memecahkan masalah. Model Team Assisted Individualization (TAI) merupakan salah satu dari model pembelajaran kooperatif yang di bentuk dari kelompokkelompok kecil dalam kelas yang heterogen dalam setiap kelompok dan 
diikuti dengan pemberiaan bantuan dari siswa yang pandai anggota kelompok secara individual bagi peserta didik yang memerlukan. (Tinungki, 2015)

Tabel 1. Langkah-langkah Model Pembelajaran Kooperatif Tipe TAI

\section{Assisted \\ Individualization (TAI) \\ 1. Teams}

Unsur Pembelajaran Langkah-langkah Kooperatif Tipe Team pembelajaran

2. Placement test

3. Teaching Group

4. Student Creative

5. Team study

6. Whole-class Units

a. Pembagian
Pembentukan kelompok di mana siswa dibagi menjadikelompok kecil yang beranggotakan 4-5 orang.

Prosedur pembentukan berdasar pre-test himpunan dan rangking berdasarkan perolehan nilai. handout untuk masing-masing siswa.

b. Penjelasan secara singkat pokok materi yang akan dibahas pada pertemuan itu oleh guru.

Siswa belajar secara individu materi yang terdapat pada handout dan mengerjakan soal.

Siswa berdiskusi tentang materi dan mengoreksi jawaban dengan teman satu kelompok.

a. Perawakilan kelompok maju untuk mempresentasika n hasil kerja kelompok.

b. Kelompok lain memberikan tanggapan pertanyaan.

c. Evaluasi hasil diskusi dan penyempurnaan

\section{Unsur Pembelajaran Kooperatif Tipe Team Assisted \\ Individualization (TAI)}

jawaban siswa oleh guru.

7. Facts test

Pelaksanaan tes akhir dan siswa mengerjakannya secara individu.

8. Teams Scores and Pengumuman skor Team Recognition tiap kelompok selama satu siklus dan pemberian penghargaan bagi kelompok super, kelompok hebat, dan kelompok baik.

(Fathurrohman, 2015)

Skor kelompok diperoleh dengan menghitung rata-rata skor peningkatan individu. Pemberian skor berguna untuk memotivasi siswa Diperoleh dengan menghitung selisih antara skor tes dasar dan skor tesagar bekerja keras memperoleh hasil yang lebih baik dibandingkan dengan hasil yang telah dicapai sebelumnya. Skor peningkatan individuakhir. Dari selisih nilai yang diperoleh dapat dilihat pada tabel 2 .

Tabel 2. Perhitungan Skor Peningkatan Individu

\begin{tabular}{cll}
\hline No. & \multicolumn{1}{c}{ Nilai Tes } & \multicolumn{1}{c}{$\begin{array}{c}\text { Skor } \\
\text { Perkembangan }\end{array}$} \\
\hline 1. & $\begin{array}{l}\text { Lebih dari } 10 \text { poin di } \\
\text { bawah skor awal }\end{array}$ & poin \\
2. & $\begin{array}{l}10 \text { poin di bawah } \\
\text { sampai } 10 \text { poin } \\
\text { bawah skor awal di }\end{array}$ \\
3. & $\begin{array}{l}\text { Skor awal sampai 10 } \\
\text { poin diatas skor awal }\end{array}$ \\
4. & $\begin{array}{l}\text { Lebih dari 10 poin } \\
\text { dari skor awal }\end{array}$ \\
5. & $\begin{array}{l}\text { Nilai sempurna (tanpa } \\
\text { memperhatikan skor } \\
\text { awal) }\end{array}$ \\
\hline
\end{tabular}

(Fathurrohman, 2015) 


\section{Kelebihan dan Kelemahan Model Pembelajaran Kooperatif Tipe Team Assisted Individualization (TAI)}

Abidin (2014) Seperti halnya metode lain, metode belajar kooperatif tipe Team Assisted Individualization (TAI) memiliki kelebihan- kelebihan dan kelemahan.

a. Kelebihan Model Pembelajaran Kooperatif TipeTeam Assisted Individualization(TAI)

1) Siswa akan termotivasi belajar karena hasil belajar dinilai secara teliti dan cepat.

2) Para siswa terbina kemampuan komunikasinya.

3) Perilaku yang mengganggu dan konflik antar pribadi akan terkurangi melalui penanaman prinsip kerja kooperatif.

4) Program ini sangat membantu siswa yang lemah dan sekaligus meningkatkan prestasi belajar siswa secara keseluruhan.

b. Kelemahan Model Pembelajaran Kooperatif Tipe Team Assisted Individualization (TAI)

1) Diperlukan media pembelajaran yang lengkap dan memadai.

2) Waktu yang lama untuk pembuatan perangkat pembelajaran.

3) Diperlukan kinerja kritis evaluatif dari guru selama siswa bekerja dalam kelompok.

\section{METODE PENELITIAN}

Sugiyono menjabarkan metode penelitian pada dasarnya merupakan cara ilmiah untuk mendapatkan data dengan tujuan dan kegunaan tertentu (Sugiyono, 2013). Berdasarkan hal tersebut terdapat empat kunci yang perlu diperhatikan yaitu, cara ilmiah, data, tujuan dan kegunaan. Metode eksperimen merupakan salah satu metode yang cocok digunakan untuk meningkatkan motivasi dan aktivitas peserta didik dalam pembelajaran (Marlinda, Halim, Maulana, 2016).
Jenis penelitiaan yang digunakan adalah penelitian kuantitatif dengan metode penelitiaan eksperimen. Desain penelitian yang digunakan berbentuk pretest and post-test control group design. Desain ini melibatkan dua kelompok kelas, yaitu kelompok pertama adalah kelompok eksperimen satu yang belajar dengan menggunakan model pembelajaran kooperatif tipe Team Assisted Individualization (TAI) dan kelompok kedua adalah kelompok kontrol dengan menggunakan model pembelajaran konvensional. Dalam hal ini model pembelajaran konvensional yang digunaakan adalah metode ceramah.

Populasi dalam penelitian ini adalah seluruh siswa kelas X SMA Negeri 8 Lubuklinggau yang berjumlah 123 orang. Penelitian ini mengambil sampel sebanyak dua kelas yang terdiri dari kelas eksperimen dan kelas kontrol dilakukan dengan cara simple random sampling. Alasan menggunakan simple random sampling ini karena semua populasi kelas $\mathrm{X}$ homogen dan semua populasi memiliki peluang yang sama untuk menjadi sampel. Dalam hal ini kelas X.1 sebagai kelas eksperimen 1 dan kelas X.2 sebagai kelas control. Teknik pengumpulan data dalam penelitian ini adalah tes, tes yang digunakan dalam penelitiaan ini berbentuk soal essay, dengan jumlah 7 soal yang dipakai. Analisis data dilakukan untuk mengetahui hipotesis diterima atau ditolak, maka data diuji dengan menggunakan t-tes.

\section{HASIL DAN PEMBAHASAN Hasil Penelitian}

Deskripsi data yang dimaksud adalah untuk memberikan gambaran secara umum mengenai data yang diperoleh di lapangan. Adapun sampel yang digunakan dalam peelitian ini ada dua kelas yaitu, kelas X.1 sebaagai kelas eksperimen menggunakan model pembelajaran kooperatif tipe Team Asissted Individualizatian (TAI) dan kelas X.2 
sebagai kelas kontrol menggunakan model pembelajaran konvensional. Sebelum pelaksanaan penelitian ini terlebih dahulu dilaksanakan uji coba instrumen. Pada tanggal 23 Juli 2016 peneliti melakukan uji coba instrumen terhadap siswa kelas XI IPA.1 SMA Negeri 8 Lubuklinggau dengan jumlah siswa 20 orang. Dari hasil uji kelayakan soal, dari 10 butir soal menjadi 7 butir soal yang layak untuk dijadikan instrumen tes. Untuk jumlah perlakuan tatap muka dalam penelitian ini yaitu sebanyak empat kali pertemuan yaitu dengan rincian 2 (dua) kali pertemuan mengajar 1 (satu) kali pre-test dan 1 (satu) kali post-test.

Pemberian pre-test digunakan untuk mengetahui kemampuan awal siswa. Setelah kemampuan awal siswa diketahui, dilanjutkan dengan pemberian perlakuan pada siswa, kegiatan pembelajaran dengan menggunakan model pembelajaran kooperatif tipe Team Asissted Individualization (TAI) untuk kelas eksperimen dan model pembelajaran konvensional kelas control.

Penelitian dilakukan post-test untuk mengetahui hasil akhir siswa. Pemberian perlakuan yang berbeda karena ingin membuktikan hipotesis. Adapun hipotesis dalam penelitian ini adalah "ada pengaruh model pembelajaran kooperatif tipe Team Assisted Individualization (TAI) terhadap hasil belajar fisika siswa kelas X SMA Negeri 8 Lubuklinggau tahun pelajaran 2016/2017".

Tabel 3. Rekapitulasi Hasil Pre-test Kelaseksperimen dan Kelas Kontrol

\begin{tabular}{clcc}
\hline No. & \multicolumn{1}{c}{ Uraian } & $\begin{array}{c}\text { Kelas } \\
\text { Eksperimen }\end{array}$ & $\begin{array}{c}\text { Kelas } \\
\text { control }\end{array}$ \\
\hline 1. & Jumlah siswa & 25 & 25 \\
2. & Nilai rata-rata & 40,64 & 32,16 \\
3. & Nilai tertinggi & 57,33 & 54,67 \\
4. & Nilai terendah & 24 & 21,33 \\
5. & Simpangan & 8,46 & 9,35 \\
& baku & & \\
\hline
\end{tabular}

Berdasarkan tabel 3 dapat disimpulkan bahwa nilai rata-rata kelompok eksperimen 45 dan nilai rata-rata kelompok kontrol 35,61.
Tabel 4. Hasil Uji Normalitas Nilai Pre-test

\begin{tabular}{|c|c|c|c|}
\hline $\begin{array}{c}\text { Kelas } \\
\text { Eksperimen }\end{array}$ & $\chi^{2}$ hitung & $\chi^{2}$ tabel & $\begin{array}{c}\text { Kesimpula } \\
n\end{array}$ \\
\hline Eksperimen & 5,15 & 11,070 & Normal \\
\hline Kontrol & 9,06 & 11,070 & Normal \\
\hline \multicolumn{4}{|c|}{ Tabel 5. Hasil Uji Homogenitas Nilai Pre-test } \\
\hline Data & Fhitung & $F_{\text {tabel }}$ & Kesimpulan \\
\hline Pre-test & 1,27 & 1,98 & Homogen \\
\hline
\end{tabular}

Berdasarkan tabel 5 nilai $\mathrm{F}_{\text {tabel }}$ dengan derajat kebebasan untuk pembilang $\mathrm{dk}=$ 25-1= 24, dan derajat kebebasan untuk penyebut $\mathrm{dk}=25-1=24$, dan $\alpha=0,05$. Maka $\mathrm{F}_{\text {tabel }}=1,98 . \mathrm{F}_{\text {hitung }}=1,27$ dan $\mathrm{F}_{\text {tabel }}$ $=1,98$ karena $F_{\text {hitung }}<F_{\text {tabel }}$, dengan demikian kedua kelas pre-test (kelas eksperimen dan kelas kontrol) adalah homogen. Untuk mengetahui perhitungan uji homogenitas.

Tabel 6.Hasil Uji Kesamaan Dua Rata-rata Pre-test

\begin{tabular}{cccc}
\hline Data & $\mathbf{t}_{\text {hitung }}$ & $\mathbf{t}_{\text {tabel }}$ & \multicolumn{1}{c}{ Kesimpulan } \\
\hline $\begin{array}{c}\text { Pre }- \\
\text { test }\end{array}$ & 1,81 & 2,021 & $\begin{array}{l}\mathrm{t}_{\text {hitung }}<\mathrm{t}_{\text {tabel }}, \text { maka } \mathrm{H}_{0} \\
\text { diterima }\end{array}$ \\
\hline
\end{tabular}

Berdasarkan $\mathrm{dk}=48$ dan $\alpha=0,05$, maka nilai $t_{\text {tabel }}$ adalah 2,021. Jadi $t_{\text {hitung }}<$ $\mathrm{t}_{\text {tabel}}$, maka $\mathrm{H}_{0}$ diterima. Artinya kedua rata-rata skor pre-test kelas eksperimen dan klas kontrol adalah sama.

Tes akhir siswa (post-test) juga digunakan untuk mengetahui perbandingan hasil belajar fisika siswa kelas eksperimen dan kelas kontrol.

Tabel 7. Rekapitulasi Hasil Post-test

\begin{tabular}{|c|c|c|c|}
\hline No & Uraian & $\begin{array}{c}\text { Kelas } \\
\text { Eksperimen }\end{array}$ & $\begin{array}{c}\text { Kelas } \\
\text { Kontrol }\end{array}$ \\
\hline 1 & $\begin{array}{l}\text { Jumlah } \\
\text { Siswa }\end{array}$ & 25 & 25 \\
\hline 4 & $\begin{array}{l}\text { Nilai Rata- } \\
\text { rata }\end{array}$ & 83,41 & 75,73 \\
\hline 5 & $\begin{array}{l}\text { Simpangan } \\
\text { Baku }\end{array}$ & 12,00 & 8,84 \\
\hline & $\begin{array}{l}\text { erdasarkan } \\
\text { bitilasi da } \\
\text { atakan siswa } \\
\text { ar setelah } \\
\text { erimen dan } \\
\text { kuan denga }\end{array}$ & $\begin{array}{l}\text { tabel } 7 \\
\text { ta post-te } \\
\text { mengalami p } \\
\text { masing-mas } \\
\text { kelas cont } \\
\text { nilai rata- }\end{array}$ & $\begin{array}{lr}\text { ri } & \text { hasil } \\
\text { ningkatan } \\
\text { ning } \\
\text { ig kelas } \\
\text { ol diberi } \\
\text { ata kelas }\end{array}$ \\
\hline
\end{tabular}


rata kelas kontrol sebesar 75,73. Dari data tersebut menunjukan selisih nilai rata-rata post-test kelas eksperimen dan kelas kontrol adalah 7,68.

Tabel 8. Hasil Uji Normalitas Nilai Post-test

\begin{tabular}{lccc}
\hline $\begin{array}{c}\text { Kelas } \\
\text { Eksperimen }\end{array}$ & $\begin{array}{c}\boldsymbol{\chi}_{\text {hitun }}^{\mathbf{2}} \\
\mathbf{g}\end{array}$ & $\boldsymbol{\chi}^{\mathbf{2} \text { tabel }}$ & $\begin{array}{c}\text { Kesimp } \\
\text { ulan }\end{array}$ \\
\hline Eksperimen & 8,40 & 11,070 & Normal \\
\hline Kontrol & 1,45 & 11,070 & Normal \\
\hline
\end{tabular}

Tabel 9. Hasil Uji Homogenitas Nilai Post-test

\begin{tabular}{cccc}
\hline Data & $\mathbf{F}_{\text {hitung }}$ & $\mathbf{F}_{\text {tabel }}$ & Kesimpulan \\
\hline POst-test & 1,84 & 1,98 & Homogen
\end{tabular}

Berdasarkan tabel 8 nilai $\mathrm{F}_{\text {tabel }}$ dengan derajat kebebasan untuk pembilang $\mathrm{dk}=$ 25-1= 24, dan derajat kebebasan untuk penyebut $\mathrm{dk}=25-1=24$, dan $\alpha=5 \%$. Maka $F_{\text {tabel }}=1,98 . F_{\text {hitung }}=1,84$ dan $F_{\text {tabel }}$ $=1,98$ karena $F_{\text {hitung }}<F_{\text {tabel, }}$, dengan demikian kedua kelas post-tes (kelas eksperimen dan kelas kontrol) adalah homogen.

Tabel 10. Hasil Uji Kesamaan Dua Rata-rata Post-test

\begin{tabular}{cccc}
\hline Data & $\mathrm{t}_{\text {hitung }}$ & $\mathrm{t}_{\text {tabel }}$ & \multicolumn{1}{c}{ Kesimpulan } \\
\hline $\begin{array}{c}\text { Post- } \\
\text { test }\end{array}$ & 2,604 & 1,684 & $\begin{array}{l}\mathrm{t}_{\text {hitung }}>\mathrm{t}_{\text {tabel }}, \text { maka } \mathrm{H}_{0} \\
\text { ditolak }\end{array}$ \\
\hline
\end{tabular}

Berdasarkan tabel 10 menunjukan bahwa hasil analisis uji $t$ pada kemampuan akhir siswa adalah dengan $\mathrm{dk}=48$, dengan taraf signifikan $\alpha=5 \%$ maka nilai $t_{\text {tabel }}$ adalah 1,684. Jadi $t_{\text {hitung }}>$ $\mathrm{t}_{\text {tabel, }}$ maka terima $\mathrm{H}_{\mathrm{a}}$ dan tolak $\mathrm{H}_{0}$. Dengan kata lain "ada pengaruh model pembelajaran kooperatif tipe Team Asissted Individualization (TAI) terhadap hasil belajar fisika".

Tabel 11.Nilai Rata-rata $(\bar{x})$ dan Simpangan Baku (s) Hasil Pre-test dan Post-test

\begin{tabular}{|c|c|c|c|c|}
\hline \multirow[b]{2}{*}{ Data } & \multicolumn{2}{|c|}{ Eksperimen } & \multicolumn{2}{|c|}{ Kontrol } \\
\hline & $\begin{array}{l}\text { Nilai } \\
\text { Rata- } \\
\text { rata }(\bar{x} \\
\text { ) }\end{array}$ & $\begin{array}{c}\text { Simpa } \\
\text { ngan } \\
\text { Baku }\end{array}$ & $\begin{array}{c}\text { Nilai } \\
\text { Rata- } \\
\text { rata }(\bar{x})\end{array}$ & $\begin{array}{c}\text { Simpan } \\
\text { gan } \\
\text { Baku }\end{array}$ \\
\hline $\begin{array}{l}\text { Pre- } \\
\text { test }\end{array}$ & 40,64 & 8,46 & 32,16 & 9,35 \\
\hline
\end{tabular}

\begin{tabular}{lllll}
\hline $\begin{array}{l}\text { Post }- \\
\text { test }\end{array}$ & 83,41 & 12,00 & 75,73 & 8,84 \\
\hline
\end{tabular}

Berdasarkan tabel 11, dapat dijelaskan bahwa nilai rata-rata kelas eksperimen hasil pre-test adalah 40,64 dan hasil posttest adalah 83,41, untuk simpangan baku hasil pre-test 8,46 dan hasil post-test 12,00 . Sedangkan kelas kontrol nilai ratarata pre-test adalah 32,16 dan post-test 75,73 untuk simpangan baku pre-test 9,35 dan post-test adalah 8,84. Sehingga dapat dikatakan, bahwa nilai rata-rata hasil belajar fisika siswa yang menggunakan model pembelajaran kooperatif tipe Team Asissted Individualization (TAI) lebih tinggi dari nilai rata-rata kelas kontrol dilihat dari nilai rata-rata hasil pre-test dan post-test

\section{Pembahasan}

Hasil kuis siswa yang dijarkan dengan menggunakan model pembelajaran tipe Team Asissted Individualization (TAI) terdapat satu kelompok yang mendapat penghargaan super dengan poin peningkatan kelompok (PKK) sebesar 26 jumlah skor kelompok adalah 130 diraih kelompok 1. Satu kelompok mendapat penghargaan hebat dengan poin peningkatan kelompok (PPK) sebesar 22 diraih kelompok 3 dengan skor kelompok berjumlah 110. Tiga kelompok lainnya mendapat penghargaan baik diraih oleh kelompok 4, 2, dan 5 dengan poin peningkatan kelompok (PPK) berturutturut sebesar 18, 12, dan 8. Jumlah skor yang diraih oleh kelompok berturut-turut adalah 90, 60 dan 40.

Penggunakan model pembelajaran tipe Team Asissted Individualization (TAI) siswa merasa tertantang untuk belajar lebih aktif, berusaha untuk percaya diri secara individual maupun interaksi sesama kelompok, serta ingin selalu mengembangkan kemampuan sehingga siswa dapat memperoleh hasil belajar yang baik (Saregar et al., 2017; Wardani et al., 2015). Abidin (2013) menyatakan 
bahwa siswa yang dijarkan menggunakan model pembelajaran tipe Team Asissted Individualization (TAI) akan termotivasi belajar karena hasil belajar dinilai secara teliti dan cepat dan siswa terbina kemampuan komunikasinya.

\section{SIMPULAN}

Berdasarkan hasil penelitian dan pembahasan yang telah diuraikan sebelumnya, dapat dilihat dari bukti uji hipotesis dengan $t_{\text {hitung }}=2,604 \mathrm{dk}=48$, taraf signifikan $\alpha=5 \%$ maka nilai tabel adalah 1,684. Jadi $t_{\text {hitung }}>t_{\text {tabel }},(2,604>$ 1,684), maka terima $\mathrm{H}_{\mathrm{a}}$ dan tolak $\mathrm{H}_{0}$. Maka, dapat disimpulkan ada pengaruh hasil belajar fisika siswa yang dibelajarkan menggunakan model pembelajaran Team Asssisted Individualization (TAI).

\section{SARAN}

Berdasarkan hasil penelitian, maka peneliti menyampaikan saran-saran kiranya dapat dipertimbangkan untuk kelangsungan proses pembelajaran selanjutnta, yaitu:

1. Siswa diharapkan lebih aktif, berani dan percaya diri dalam mengungkapakan gagasannya dalam menjawab pertanyaan dan bisa bertindak sebagai guru bagi temantemannya. Serta dapat menyelesaikan soal-soal yang diberikan oleh guru secara berkelompok dan saling bekerja sama dan tetap semangat dalam pembelajaran.

2. Guru diharapakan dapat memperbaiki dan meningkatkan sistem pembelajaran fisika dengan menggunakan model pembelajaran yang bervariasi agar siswa lebih aktif dalam proses pembelajaran.

3. Sekolah diharapkan lebih memperhatikan sarana dan prasarana berupa buku-buku pelajaran guna untuk menunjang kegiatan proses belajar mengajar.

\section{DAFTAR PUSTAKA}

Abidin. (2013). Desain Sistem Pembelajaran dalam Konteks Kurikulum 2013. Bandung: Refika Aditama.

Erlinda, N. (2017). Peningkatan Aktivitas dan Hasil Belajar Siswa melalui Model Kooperatif Tipe Team Game Tournament pada Mata Pelajaran Fisika di SMK. Jurnal Keguruan Dan Ilmu Tarbiyah, 2(1), 47-52. https://doi.org/10.24042/tadris.v2i1.1 738

Fathurrohman. (2015). Model-model Pembelajaran Inovatif. Jogjakarta: Ar-Ruzz Media.

Gumrowi, A. (2016a). Meningkatkan Hasil Belajar Listrik Dinamik menggunakan Strategi Pembelajaran Team Assisted Individualization melalui Simulasi Crocodile Physics. Jurnal Ilmiah Pendidikan Fisika AlBiruni, 5(1), 105-111. https://doi.org/10.24042/jpifalbiruni. v5i1.110

Gumrowi, A. (2016b). Strategi Pembelajaran melalui Pendekatan Kontekstual dengan Cooperative Learning untuk Meningkatkan Hasil Belajar Gelombang Siswa Kelas XII MAN 1 Bandar Lampung. Jurnal Ilmiah Pendidikan Fisika Al-Biruni, 5(2), 183-191. https://doi.org/10.24042/jpifalbiruni. v5i2.118

Herlanti, Y., Rustaman, N. Y., Rohman, I., \& Fitriani, A. (2012). Kualitas Argumentasi pada Diskusi Isu Sosiosaintifik Mirobiologi melalui Weblog. Jurnal Pendidikan IPA Indonesia, 1(2), 168-177.

Hermawan, H., \& Paloloang, B. (2014). Penerapan Model Pembelajaran Kooperatif Tipe Team Assisted Individualization ( TAI ) Untuk Meningkatkan Hasil Belajar Siswa Kelas V SDN 4 Bajugan Pada Operasi Hitung Campuran. Jurnal Kreatif Tadulako Online, 4(9), 44- 
60.

Khusaini. (2017). Analysis of Prospective Physics Teachers' Feedback on Online Peer-Assesment. Jurnal Pendidikan Fisika Indonesia, 13(1), 41-48. https://doi.org/10.15294/jpfi.v13i1.6 509

Komikesari, H. (2016). Peningkatan Keterampilan Proses Sains dan Hasil Belajar Fisika Siswa pada Model Pembelajaran Kooperatif Tipe Student Team Achievement Division. Jurnal Keguruan Dan Ilmu Tarbiyah, 1(1), 15-22.

Marlinda. Abdul Halim. Ilham Maulana. (2016). Perbandingan Penggunaan Media Virtual Lab PhET (Physics Education Tekhnology) dengan Metode Eksperimen terhadap Motivasi dan Aktivitas Belajar Peserta Didik pada Materi Kelarutan dan Hasil Kali Kelarutan. Jurnal Pendidikan Sains Indonesia, 4(2), 69-82.

Perdana, A. S. S. (2017). Pengembangan Lembar Kerja Siswa Berbasis Discovery Learning Berbantukan PhET Interactive Simulations pada Materi Hukum Newton. Jurnal Wahana Pendidikan Fisika, 2(1), 73-79.

Rusman. (2013). Model-model pembelajaran: Mengembangkan Profesionalisme Guru Edisi Kedua. Jakarta: Raja Grafindo Persada.

Saregar, A., Diani, R., \& Kholid, R. (2017). Efektivitas Penerapan Model Pembelajaran ATI ( Aptitude Treatment Interaction ) Dan Model Pembelajaran TAI ( Team Assisted Individualy ): Dampak Terhadap Hasil Belajar Fisika Siswa, 3(1), 2835.

Saregar, A., Latifah, S., \& Sari, M. (2016). Efektivitas Model Pembelajaran CUPs: Dampak terhadap Kemampuan Berpikir Tingkat Tinggi Peserta Didik
Madrasah Aliyah Mathla'ul Anwar Gisting Lampung. Jurnal Ilmiah Pendidikan Fisika Al-Biruni, 5(2), 233-243.

https://doi.org/10.24042/jpifalbiruni. v5i2.123

Sugiyono. (2013). Statistika untuk Penelitian. Bandung: Alfabeta.

Tinungki, G. M. (2015). The Role of Cooperative Learning Type Team Assisted Individualization to Improve the Students ' Mathematics Communication Ability in the Subject of Probability Theory. Journal Of Education and Practice, 6(32), 27-31.

Trianto. (2013). Mendesain Model Pembelajaran Inovatif-Progresif: Konsep, Landasan, dan Implementasinya dalam Kurikulum Tingkat Satuan Pendidikan (KTSP. Jakarta: Kencana Prenada Media.

Wardani, N. C. A., Suwatra, I. W., \& Wirya, N. (2015). Pengaruh Model Pembelajaran Team Assisted Individualization ( TAI ) terhadap Hasil Belajar Mata Pelajaran IPA pada Siswa Kelas VII Tahun Ajaran 2014/2015 di SMP NEGERI 1 BANJAR. Jurnal Edutech, 2(1).

Yulianti, D., \& Putra, N. M. D. (2012). Upaya Mengembangkan Learning Community Siswa Kelas X SMA melalui Penerapan Model Pembelajaran Kooperatif Tipe STAD Berbasis CTL pada Pembelajaran Fisika. Jurnal Pendidikan IPA Indonesia, 1(1), 57-62. 